\title{
Protein Mediated Silica Particles with pH Controlled Porosity and Morphology
}

\author{
Shilpi Show, Brajadulal Chattopadhyay* \\ Department of Physics, Jadavpur University, Kolkata, India \\ Email: ^bdc_physics@yahoo.co.in
}

How to cite this paper: Show, S. and Chattopadhyay, B. (2016) Protein Mediated Silica Particles with $\mathrm{pH}$ Controlled Porosity and Morphology. Advances in Microbiology, 6, 986-998.

http://dx.doi.org/10.4236/aim.2016.614093

Received: November 2, 2016

Accepted: December 3, 2016

Published: December 7, 2016

Copyright $\odot 2016$ by authors and Scientific Research Publishing Inc. This work is licensed under the Creative Commons Attribution International License (CC BY 4.0).

http://creativecommons.org/licenses/by/4.0/

(c) $\underset{\mathrm{EY}}{\mathrm{i}}$ Open Access

\begin{abstract}
Background: The silica leaching activity of some of the mystifying non-pathogenic $\mathrm{BKH} 1$ bacteria present in the cluster of hot springs (temperatures range $35^{\circ} \mathrm{C}-80^{\circ} \mathrm{C}$ ) at Bakreshwar (West Bengal, India, $23^{\circ} 52^{\prime} 48^{\prime \prime} \mathrm{N} ; 8^{\circ} 22^{\prime} 40^{\prime \prime} \mathrm{N}$ ) has provided some significant advancements in the field of nanotechnology. The present investigation was designed to synthesis the silica particles using bioremediase protein at different $\mathrm{pH}$ conditions. Methods: A secretary bacterial protein bioremediase (UniProt Knowledgebase Accession Number P86277) isolated from a thermophilic non-pathogenic bacterium BKH1 (GenBank Accession No. FJ177512) has been used to synthesis the silica particles at different $\mathrm{pH}$ conditions $(\mathrm{pH}$ at 3.0, 5.0, 8.0, 10.0, and 12.0 respectively). The silica particles were synthesized by the action of bioremediase protein on Tetra-ethyl-orthosilicate (TEOS) under ambient condition. Morphological and compositional studies of the biosynthesized silica particles were characterized by Field emission scanning electron microscope (FE-SEM) equipped with Energy dispersive X-ray analyser (EDX). Results: The Fourier transformed infra-red (FTIR) spectroscopic analysis confirmed the nature as well as occurrence of several functional groups surrounded on the silica particles. The amorphous nature of the prepared silica particles was confirmed by X-ray diffractometer (XRD) study. The Zeta potential

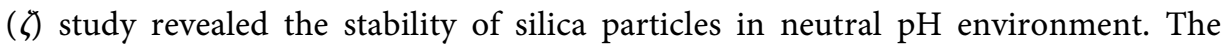
Brunauer-Emmett-Teller (BET) surface area measurement confirmed the porosity variation in all biosynthesized silica particles prepared at different $\mathrm{pH}$ conditions. Raman spectra analytically depend on their respective specific surface (BET) area. Thermogravimetry tool was used to monitor the effects of the thermal treatment on the surface properties of all the samples. Conclusions: The method for the synthesis of silica particles at different $\mathrm{pH}$ condition using the protein bioremediase has a special implication as it is an environmentally benign, cost-effective and facile technique which may have conceivable application in chromatographic packing. In addition, controlling of size as well as porosity of the silica particles can be achievable by $\mathrm{pH}$ as an only variable.
\end{abstract}




\section{Keywords}

Bioremediase Protein, Tetraethyl Orthosilicate, Green Chemistry, Silica Particles, Porosity

\section{Introduction}

Porous materials have stimulated growing interests due to their wide-ranging prospective utilizations in several applications fields e.g., as catalysis, drug delivery, chemical sensors, chromatography, micro reactor and biological images [1]-[6]. Silica particles have been established as probable promising material due to its some distinctive properties [7] [8]. On the other hand, the use of silica-based chromatographic packing is usually popular because of the mechanically, thermally and chemically stable bonded phases in the $\mathrm{pH}$ range of about 2 to 8 . The $\mathrm{pH}$ value can be extended up to 11 using double end-capped silica-based bonded phases with organic buffers below $313 \mathrm{~K}$ [9]. At low $\mathrm{pH}$ value, the chemically bonded ligands are slowly detached from the surface via the process of hydrolysis of siloxane linkages [10]. On the other hand disbanding of the silica matrix will take place at higher $\mathrm{pH}$ value. Due to the low stability of silica-based materials at low and high $\mathrm{pH}$ values, other porous inorganic oxides like alumina, zirconia, titania etc. are often used. But the commercial availability of inorganic oxides like alumina, zirconia, titania etc. are limited as compare to silica-based materials [11]. So, now a day it is more desired to prepare materials with controlled shape and pore size having commercial importance. Silica is most usable and commercially available inorganic oxide for chromatographic packing applications.In general, the technique used for synthesis of silica particlesis sol-gel methods. Appetence in the sol-gel processing of ceramic and glass materials on Silica gels preparation was done [12]. Stober proposed first mono-disperse and nonporous silica spheres with the hydrolysis of tetra-ethyl-orthosilicate (TEOS) in strongly basic medium. Stober and Fink well established theaction of mechanism involved in the formation of silica nanoparticles $\left(\mathrm{SiO}_{2}\right.$-NPs) [13] [14]. Bogush and Zukoski procured mono-dispersed $\mathrm{SiO}_{2}$-NPs with controlled hydrolysis of TEOS in ethanol [15]. Sung Kyoo Park provided $\mathrm{SiO}_{2}$-NPs from TEOS in ethanol by using a semi-batch process in order to control the particle properties [16]. Butnow it becomes a high demanding field to focus on the more eco-friendly and green facile synthesis technique of $\mathrm{SiO}_{2}$-NPs. In the present work, we recommended a single step, rapid and simple technique for the formation of amorphous, along with thermally and chemically stable silica particles with controlled size using a microbial secretary protein (bioremediase) at different $\mathrm{pH}$ conditions and its plausible application in the field of chromatographic packing.

\section{Material and Methods}

\subsection{Preparation of Materials}

\subsubsection{Reactants}

The bacterial strain BKH1 (Gen Bank accession number FJ177512) was obtained from 
the Biophysics Laboratory, Department of Physics, Jadavpur University [17] [18]. The analytical grade TEOS was purchased from the Merck, USA. All other fine chemicals were purchased from Spectro. Chem. Pvt. Ltd. India.

\subsubsection{Isolation and Purification of the Bioremediase Protein}

Bioremediase protein is secreted by the bacterium $\mathrm{BKH} 1$ in the growth medium while growing in the medium at $\mathrm{pH} 8.0$ and temperature $65^{\circ} \mathrm{C}$. The bacteria are cultured a sealed glass pressure vial anaerobically (in presence of $\mathrm{CO}_{2}$ atmosphere) [17]. The growth medium consists of $\mathrm{Fe}(\mathrm{OH})_{3}-0.1 \mathrm{M}, \mathrm{Na}_{2} \mathrm{HPO}_{4}-0.6 \mathrm{~g} / \mathrm{L}, \mathrm{KCl}-0.33 \mathrm{~g} / \mathrm{L}$, $\mathrm{Na}_{2} \mathrm{CO}_{3}-2.5 \mathrm{~g} / \mathrm{L}$, yeast extract $-0.02 \%$ and peptone $\left.-0.5 \%\right)$. The $\mathrm{pH}$ of the medium is kept at 8.0 and the temperature for optimum growth is maintained at $65^{\circ} \mathrm{C}$ temperature [17]. The enzyme was purified from 6 to 7 days old bacterial culture medium similarly as described by Biswas et al. [18]. The bioremediase enzyme present in the growth medium was concentrated by lyophilization technique and the concentrated protein was loaded on Sephadex G-100 column for purification. Double step chromatographic technique was employed to purify the enzyme. Biosilicification assay was done to ensure the silica leaching activity of the purified protein as described earlier [18].

\subsubsection{Biosynthesis of Silica Particles}

For the biosynthesis of silica particles, the purified bioremediase bacterial protein (1 $\mathrm{mg} / \mathrm{ml}$ ) was put drop wise in a desired amount organic silica rich substrate (TEOS, 0.1 $\mathrm{mol} / \mathrm{L}$ ) solution in a $5 \mathrm{ml}$ plastic vial and kept at ambient temperature for $24 \mathrm{~h}$. Same experiment was performed by making the reaction mixture at different $\mathrm{pH}$ conditions (at 3, 5, 8, 10 and 12). After adding the protein, a spherical structure of silica particles was produced within the reaction mixture. The bio-transformed reaction commodities were collected using a long for-shape. Afterwards, the product was subsequently washed twice with ethanol-deionized (DI) water solution and dried at $65^{\circ} \mathrm{C}$ temperature in vacuum desiccators for $24 \mathrm{~h}$. Finally, the dried balls were crushed by mortar pestle to get fine powder for further auxiliary characterizations. Fineness of the powder was formed mechanically as far as practicable.

\subsection{Particles Characterizations}

\subsubsection{Optical and Electron Microscopy}

The as-prepared silica particles powder sample was dispersed in DI-water and the optical characterizations were performed with UV-Vis spectrophotometer (UV-3101PC, Shimadzu). The surface morphology images and compositional compositions of the biosynthesized silica particles were investigated in Field Emission Scanning Electron Microscopy (FE-SEM, FEI INSPECT F50) equipped with Energy dispersive spectrometer (EDX, Bruker System).

\subsubsection{Zeta Potential}

The synthesized silica particles powder was dispersed in Milli-Q water and the particles size as well as zeta potential experiments were characterized through DLS (Zeta Sizer, 
Nano ZS 90, Malvern) experiment.

\subsubsection{X-Ray Diffraction}

XRD measurements of as-prepared powder silica particles sample was carried out on a Bruker, D8 Advance, X-ray diffractometre instrument operated at a voltage of $40 \mathrm{kV}$ and a current of $40 \mathrm{~mA}$ with $\mathrm{Cu}-\mathrm{K}_{\alpha}$ radiation.

\subsubsection{FTIR and Raman Spectra Analysis}

FTIR was used to identify the types of chemical bonds and functional groups presents in silica particles. The prepared silica particles powder was dried and crushed with $\mathrm{KBr}$ (1\% wt), pelleted and the FTIR spectra were recorded on a FTIR-8700, Shimadzu one instrument at a resolution of $4 \mathrm{~cm}^{-1}$. The Raman spectroscopy for the as-prepared silica particles was carried out using Laser Raman spectrometer (alpha 300, Witec, Germany) with the excitation wavelength of $532 \mathrm{~nm}$ and $20 \mathrm{~mW}$ output power for the irradiation time of 5 seconds.

\subsubsection{Thermo-Gravimetric Weight-Loss Analysis (TGA)}

The thermal stability of silica particles was observed by determining the weight loss of the sample against elevated temperature in TGA/SDTA $851{ }^{\mathrm{e}}$ Mettler Toledo thermal analyzer system.

\subsubsection{Nitrogen Adsorption-Desorption}

An adsorption-desorption isotherm of nitrogen on prepared silica particles was performed by Brunauer-Emmett-Teller (BET) surface area analyser, SA 3100, Beckman Coulter, Switzerland.

\subsubsection{Statistical Analysis}

For each experiment all prepared samples were tested repeatedly. Each experiment was repeated at least three times. Data were presented as average and \pm SD where ever is possible.

\section{Results and Discussions}

\subsection{Morphological and Compositional Characterization of Silica Particles}

Figures 1(a)-(e) specified the FESEM images of the as prepared silica particles formed by the interaction between bioremediase protein and TEOS solution at different $\mathrm{pH}$ values. It confirmed the formation of Silica particles. The size of the particles varied from few nanometres to few micrometres which were shown in Table $1(\mathrm{n}=100)$. FESEM images also concluded the fact that the variation of shape as well as the size of the prepared Silica particles directly depend on the condition of $\mathrm{pH}$ of the reaction medium. The synthesized particles were quite regular in shape and uniformly distributed for sample prepared at $\mathrm{pH}$ 8.0. EDX analysis (Figure 1(f)) of all the prepared silica particles indicated the two strong peaks which could be attributed to Silicon $(\mathrm{Si})$ and Oxygen $\left(\mathrm{O}_{2}\right)$ species. The results of EDX and FESEM analyses for the size of the silica particles were presented in Table $1(n=3)$. 

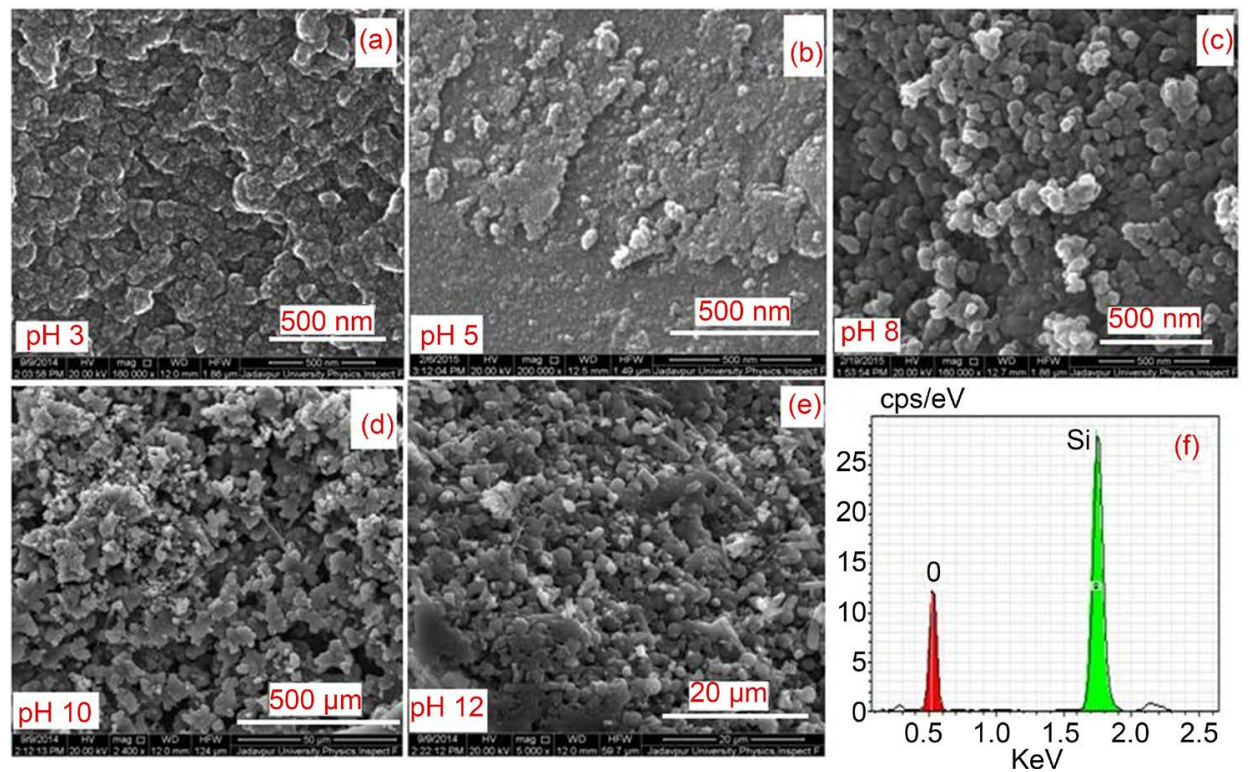

Figure 1. FE-SEM image (a)-(e) and EDX spectrum (f) of silica particle formed by the Interaction of bacterial protein with TEOS at different $\mathrm{pH}$. The experimental setup was repeated thrice and photo-micrographs were taken at different magnifications.

Table 1. Average particle size of Silica particles.

\begin{tabular}{|c|c|c|}
\hline Sample name & Average size & $\begin{array}{c}\text { Elementary analysis by EDX } \\
(\%)\end{array}$ \\
\hline $\mathrm{S}_{1}(\mathrm{pH} 3)$ & $40 \pm 10 \mu \mathrm{m}$ & $\begin{array}{l}\text { Si-66.67 } \\
\mathrm{O}_{2}-33.33\end{array}$ \\
\hline $\mathrm{S}_{2}(\mathrm{pH} \mathrm{5)}$ & $1.5 \pm 0.5 \mu \mathrm{m}$ & $\begin{array}{l}\mathrm{Si}-66.67 \\
\mathrm{O}_{2}-33.33\end{array}$ \\
\hline $\mathrm{S}_{3}(\mathrm{pH} 8)$ & $15 \pm 5 \mathrm{~nm}$ & $\begin{array}{l}\mathrm{Si}-66.67 \\
\mathrm{O}_{2}-33.33\end{array}$ \\
\hline $\mathrm{S}_{4}(\mathrm{pH} 10)$ & $3 \pm 0.5 \mu \mathrm{m}$ & $\begin{array}{l}\mathrm{Si}-66.67 \\
\mathrm{O}_{2}-33.33\end{array}$ \\
\hline $\mathrm{S}_{5}(\mathrm{pH} 12)$ & $10 \pm 2 \mu \mathrm{m}$ & $\begin{array}{l}\mathrm{Si}-66.67 \\
\mathrm{O}_{2}-33.33\end{array}$ \\
\hline
\end{tabular}

\subsection{Optical Properties}

The UV-Vis absorption spectra of silica particles suspended in DI-water exhibited an absorption peak at $\sim 360 \mathrm{~nm}$ (Figure 2). The estimated band gaps $\left(\mathrm{E}_{\mathrm{g}}\right)$ of Silica particles were tabulated in Table $2(\mathrm{n}=3)$, resembling an earlier reported value [19]. $\mathrm{SiO}_{2}$-NPs have been widely considered owing to several appealing optical phenomena caused by point defects generated from $\mathrm{SiO}_{4}$ continuous network system, including both vacancies of oxygen and silicon. This network system is denoted as a neutral (diamagnetic) oxygen vacancy that comprises a simple oxygen vacancy and twofold-coordinated silicones. Theoretical studies using initio molecular orbital calculation showed that non-paramagnetic defect is caused by a singlet-singlet transition [20] [21] [22] [23] [24]. Whereas, silica in pure state was observed as $\mathrm{UV}$-inactive and the value of $\mathrm{E}_{\mathrm{g}}$ is $\sim 5 \mathrm{eV}$. But as-prepared silica particles exhibited $\mathrm{E}_{\mathrm{g}}$ as $3.4 \pm 0.1 \mathrm{eV}$, which concluded the fact that silica particles were UV-inactive. 


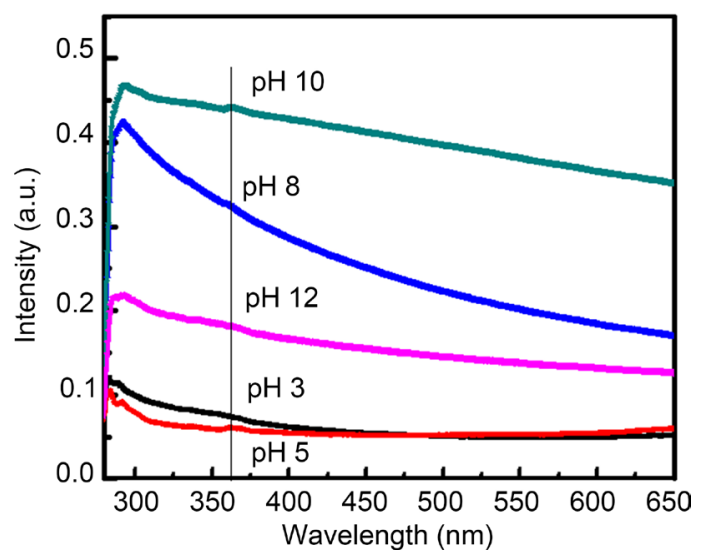

Figure 2. Absorbance spectra of the silica particles dispersed in aqueous medium. The experimental setup was repeated thrice and no differences in results were found.

Table 2. Band gap calculation of Silica particles synthesized at different $\mathrm{pH}$ values.

\begin{tabular}{ccc}
\hline Sample name & Absorption Peak $(\mathrm{nm})$ & $\begin{array}{c}\mathrm{E}_{\mathrm{g}} \text { value }(\mathrm{eV}) \\
(\mathrm{n}=3)\end{array}$ \\
\hline $\mathrm{S}_{1}(\mathrm{pH} \mathrm{3)}$ & 363 & $3.43 \pm 0.1$ \\
$\mathrm{~S}_{2}(\mathrm{pH} 5)$ & 363 & $3.43 \pm 0.1$ \\
$\mathrm{~S}_{3}(\mathrm{pH} 8)$ & 360 & $3.40 \pm 0.1$ \\
$\mathrm{~S}_{4}(\mathrm{pH} \mathrm{10)}$ & 362 & $3.43 \pm 0.1$ \\
$\mathrm{~S}_{5}(\mathrm{pH} \mathrm{12})$ & 363 & $3.43 \pm 0.1$ \\
\hline
\end{tabular}

\subsection{FTIR and XRD Study}

FTIR spectra (Figure 3) indicated the successful synthesis of silica particles by bacterial protein assisted route. Two peaks around $1097 \mathrm{~cm}^{-1}$ and $790 \mathrm{~cm}^{-1}$ were the strong evidence for presence of silicon dioxide $\left(\mathrm{SiO}_{2}\right)$ in all prepared samples. The absorption bands between 800 and $1269 \mathrm{~cm}^{-1}$ had been attributed due to the superposition of various $\mathrm{SiO}_{2}$ peaks, $\mathrm{Si}-\mathrm{OH}$ bonding and residual organic groups. Water molecules observed a strong characteristics absorption band between $3300 \mathrm{~cm}^{-1}$ and $3600 \mathrm{~cm}^{-1}$ conveyable to $\mathrm{O}-\mathrm{H}$ stretching in $\mathrm{H}$-bonded water. The scissor bending vibration of water molecule at around $1630 \mathrm{~cm}^{-1}$ band also concurred with the above information [19]. All characteristics absorption bands are tabulated in Table $3(n=3)$. Absence of any sharp crystalline diffraction peak in XRD pattern suggested the amorphous nature of silica particles (Figure 4).

\subsection{Stability of Silica Particles}

The stability of the as prepared silica particles were determined by observing the Zeta potential $(\zeta)$ of the silica particle as tabulated in Table $4(\mathrm{n}=3)$ in neutral $\mathrm{pH}$ environment (Figure 5). It suggested that silica particles surrounded with negative type of surface charges were quite stable. The negative nature of Zeta potential prevents from agglomeration and promotes stable dispersion in neutral surroundings. 


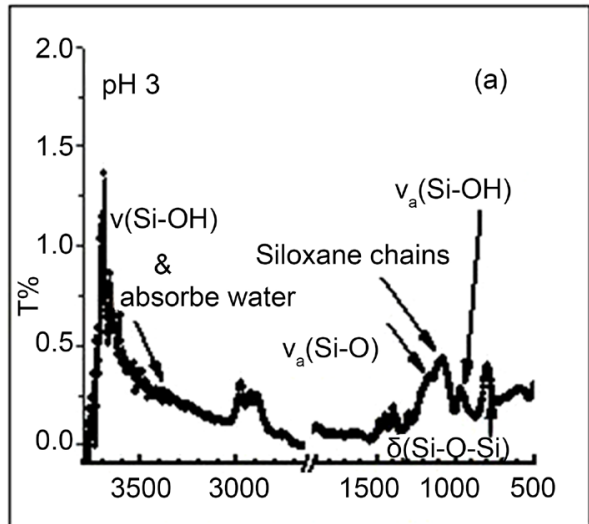

Wavenumber $\left(\mathrm{cm}^{-1}\right)$

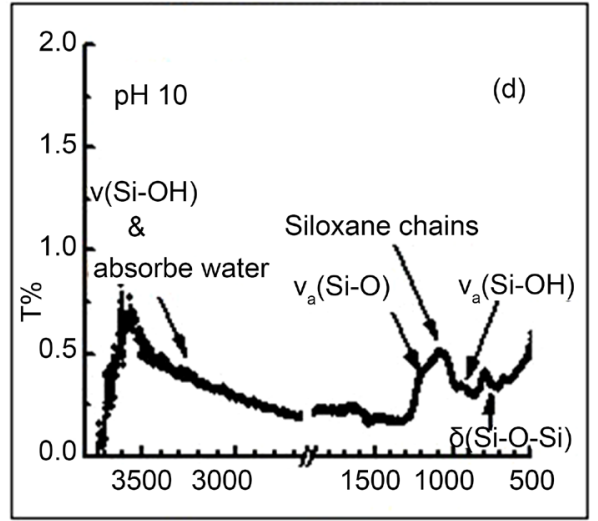

Wavenumber $\left(\mathrm{cm}^{-1}\right)$

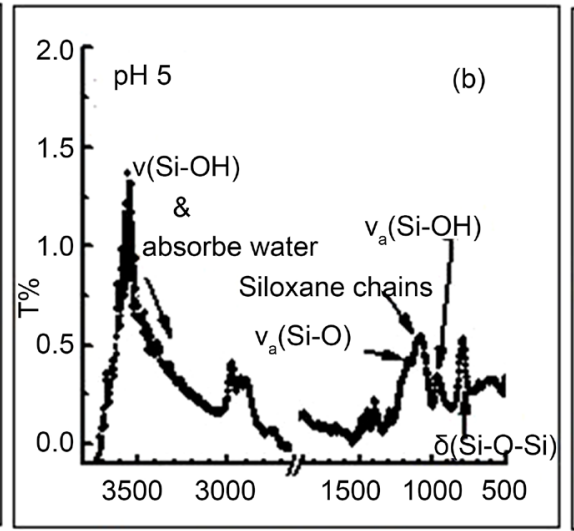

Wavenumber $\left(\mathrm{cm}^{-1}\right)$

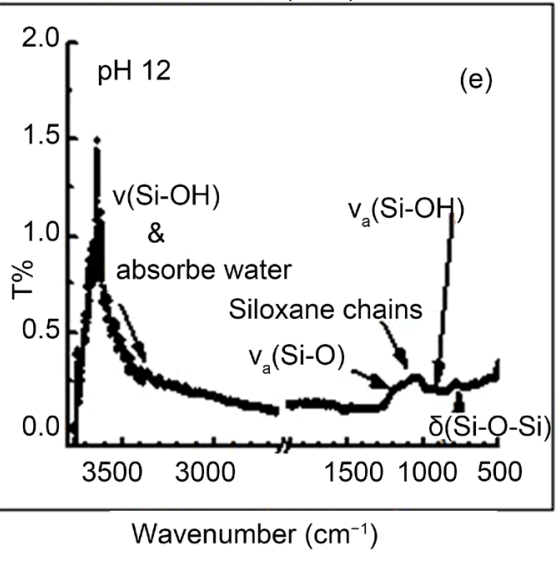

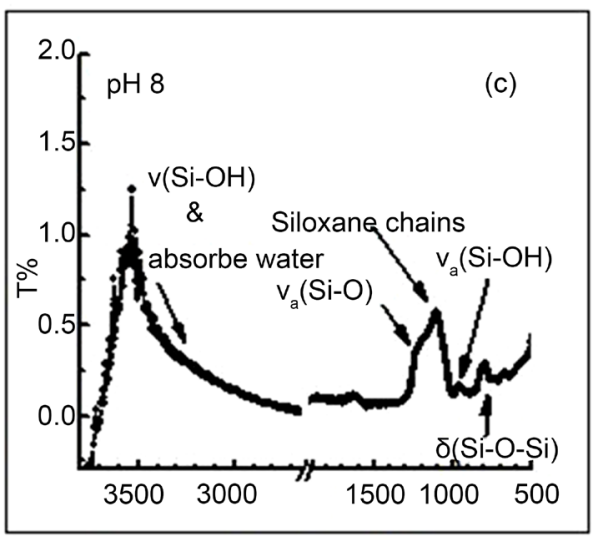

Wavenumber $\left(\mathrm{cm}^{-1}\right)$

Figure 3. FT-IR spectra (a)-(e) of the silica particle formed by the interaction of bacterial protein with TEOS at different pH. The experimental Setup was repeated thrice and no significant errors were noted.

Table 3. FTIR bands formation of Silica particles synthesized at different $\mathrm{pH}$ values.

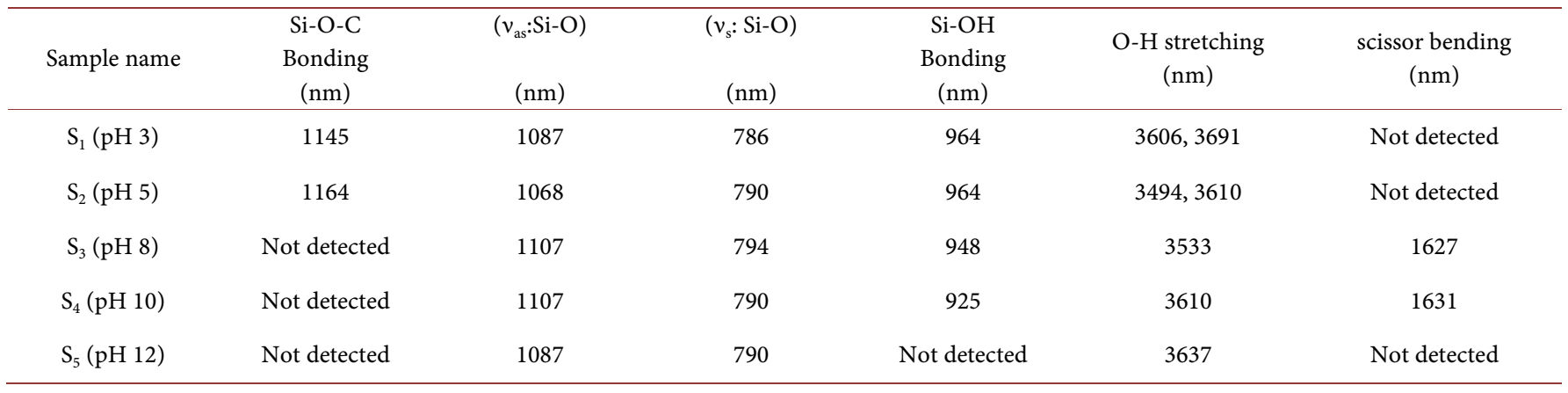

\subsection{Thermo-Gravimetric Weight-Loss Analysis}

Figure 6 indicated the thermal properties of biosynthesized silica particles measured from room temperature $\left(30^{\circ} \mathrm{C}\right)$ to a very high temperature $\left(800^{\circ} \mathrm{C}\right)$ by using TGA. TGA mainly used for characterizing the structural properties as well as for confirmation of the thermal stability of the materials. A ceramic $\left(\mathrm{Al}_{2} \mathrm{O}_{3}\right)$ crucible was used for heating and measurements were carried out in $\mathrm{N}_{2}$ atmosphere at the heating rate of $10{ }^{\circ} \mathrm{C} / \mathrm{min}$. The diminishing of mass due to thermo-desorption of the surfactant used during 

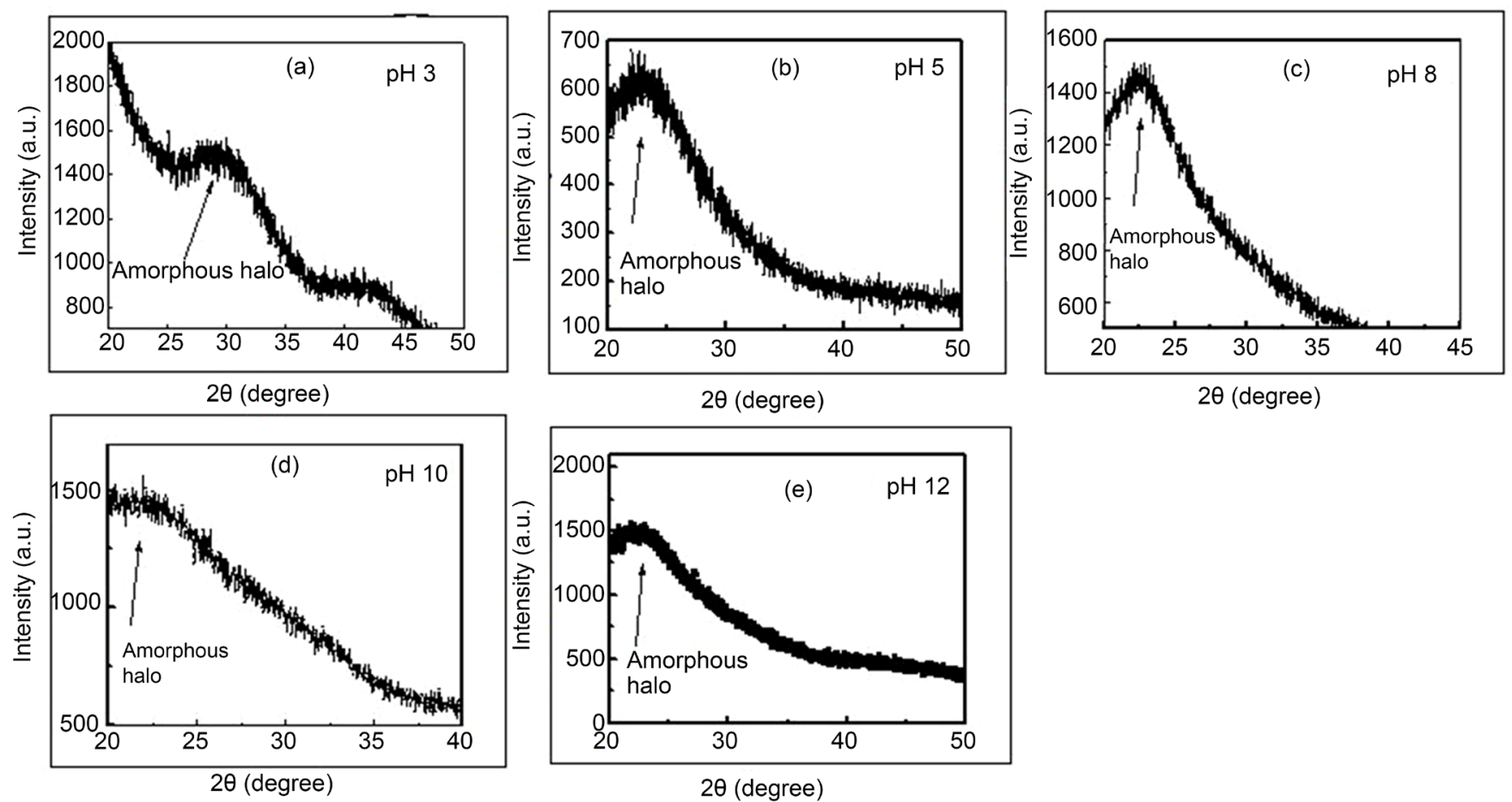

Figure 4. XRD patterns (a)-(e) of the silica particle formed by the interaction of bacterial protein with TEOS at different pH. The experimental Setup was repeated thrice and no significant errors were noted.

Table 4. Zeta Potential of Silica particles synthesized at different $\mathrm{pH}$ values.

\begin{tabular}{cc}
\hline Sample name & Zeta potential $(\zeta)$ value $(\mathrm{mV})$ \\
\hline $\mathrm{S}_{1}(\mathrm{pH} \mathrm{3})$ & $(-) 16.1 \pm 0.1$ \\
$\mathrm{~S}_{2}(\mathrm{pH} \mathrm{5})$ & $(-) 25.2 \pm 0.3$ \\
$\mathrm{~S}_{3}(\mathrm{pH} 8)$ & $(-) 43.4 \pm 0.2$ \\
$\mathrm{~S}_{4}(\mathrm{pH} \mathrm{10)}$ & $(-) 80.1 \pm 0.2$ \\
$\mathrm{~S}_{5}(\mathrm{pH} \mathrm{12)}$ & $(-) 57.4 \pm 0.3$ \\
\hline
\end{tabular}

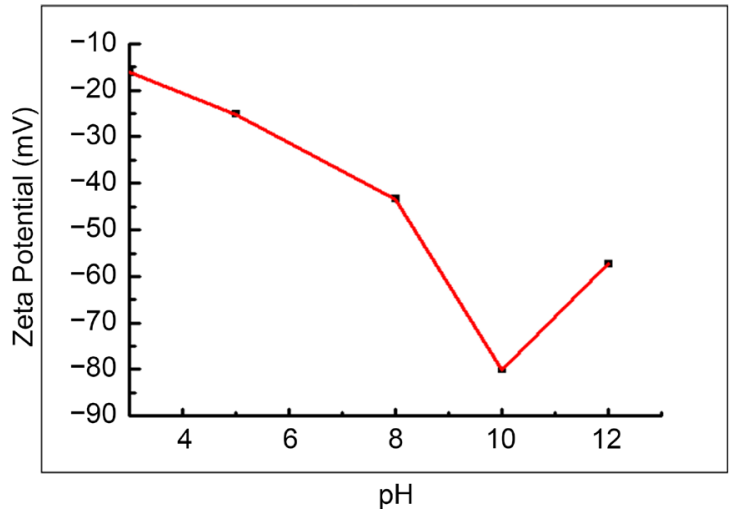

Figure 5. Zeta Potential ( $\zeta$ ) curve of synthesized silica particle formed by the interaction of bacterial protein with TEOS at different $\mathrm{pH}$ in neutral environment. The experimental setup was repeated thrice and the average with Standard Error of Zeta potential was presented. 


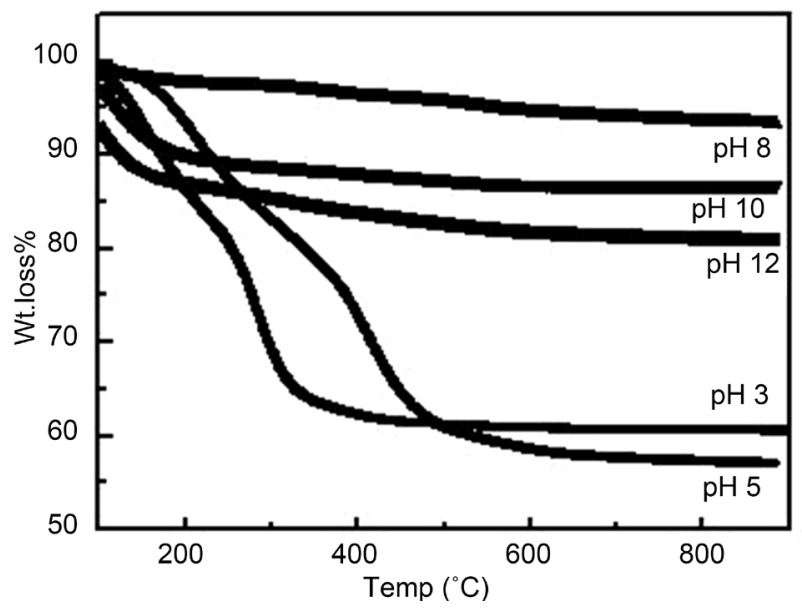

Figure 6. Thermo-gravimetric weight-loss curves for all synthesized silica particle formed by the interaction of bacterial protein with TEOS at different $\mathrm{pH}$. The experimental Setup was repeated thrice and no significant errors were noted.

preparation at low $\mathrm{pH}$ value $\left(\mathrm{pH}=3.0\right.$ and 5.0) occurred at below $300^{\circ} \mathrm{C}$. It is known that all the water molecules of the surfactant are removed when temperature is raised nearly equal to $130^{\circ} \mathrm{C}$ [11]. Between $250^{\circ} \mathrm{C}$ and $650^{\circ} \mathrm{C}$ temperature range the mass of the silica particles was almost remained constant for all samples (Figure 6). This implied that the as prepared silica particles could be used in chromatographic packing for its stability at higher temperature.

\subsection{Raman Spectra Analysis}

Figure 7 shows the Raman spectra of the as synthesized materials and conformation of the typical property of silica particles, prepared at different $\mathrm{pH}$ values. In particular, the characteristic peaks at $410 \mathrm{~cm}^{-1}$ was the due to the contribution of bending mode of oxygen in $n$-membered rings $(n>4)$ and it was well known as $R$ line; again peaks at 495 $\mathrm{cm}^{-1}$ was the breathing mode of 4-membered rings, known as $\mathrm{D}_{1}$ line; peaks at $818 \mathrm{~cm}^{-1}$ was the contribution of Silica network optical mode; vibrational mode due to $(\mathrm{OH})$ group with admiration to Si contributed the peaks at $980 \mathrm{~cm}^{-1}$. However, the amplitude of all Raman peaks systematically depends on their specific surface areas [25]. In more elaborately, the highest and lowest values of BET area found at $\mathrm{pH} 3$ and $\mathrm{pH} 12$ samples, where the intensities of all probable Raman peaks were maximum and minimum respectively. Raman peaks intensities were increasing on increasing of the specific surface as well as the value of $\mathrm{pH}$.

\subsection{Adsorption-Desorption Isotherm}

Figure 8 shows the nitrogen adsorption-desorption isotherms of all silica samples tabulated in Table $5(\mathrm{n}=3)$. They can be easily recognized by type IV adsorption isotherms with a hysteresis loops. Type IV isotherms contributed the fact that the material was mesoporous in nature. In details, for $\mathrm{S}_{1}$ the maximum (43\%) size of pore diameter $(\mathrm{nm})$ was evaluated as less than $6 \mathrm{~nm}$ and BET surface area was $119 \mathrm{~m}^{2} / \mathrm{g}$ which was 


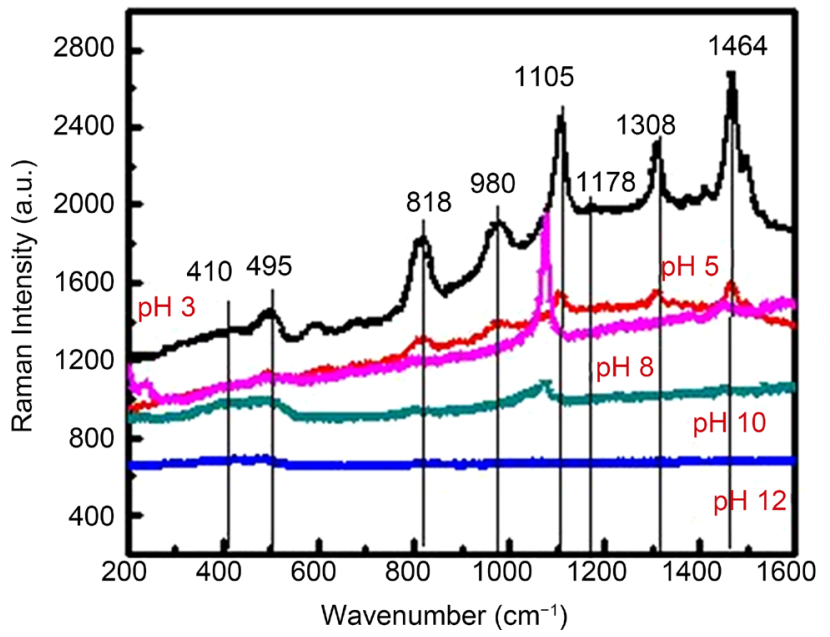

Figure 7. Raman spectra analysis for all synthesized silica particle formed by the interaction of bacterial protein with TEOS at different $\mathrm{pH}$. The experimental Setup was repeated thrice and no significant errors were noted.
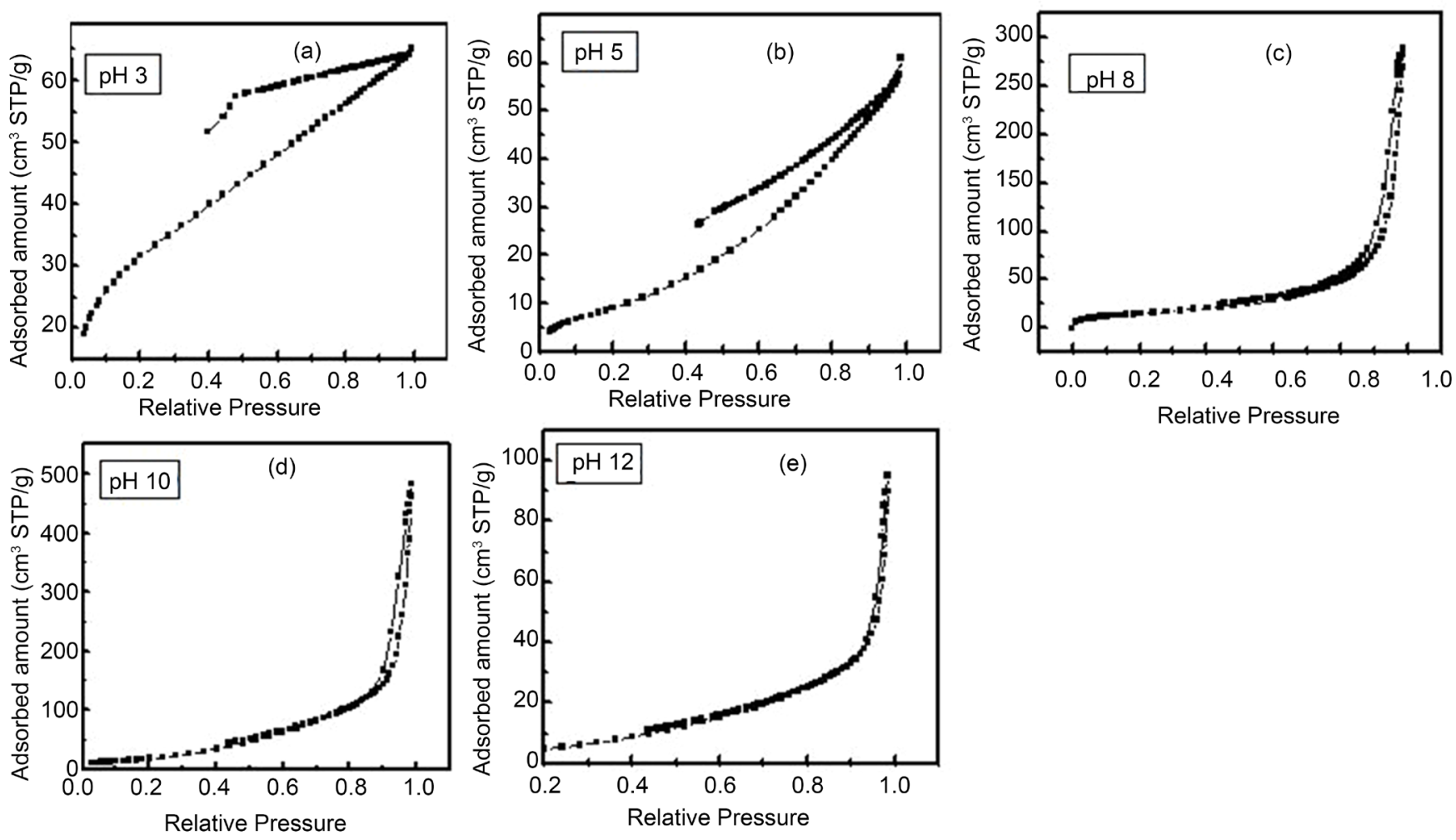

Figure 8. Nitrogen adsorption isotherms (a)-(e) for all synthesized silica particle formed by the interaction of bacterial protein with TEOS at different $\mathrm{pH}$. The experimental Setup was repeated thrice and no significant errors were noted.

concluded the fact that sample also had few micro-pores. Similarly, for all samples the BET measurement revealed the conclusions as indicated in tabulated Table $5(\mathrm{n}=3)$. From BET measurement, it was revealed that the BET surface area decreased with increasing the $\mathrm{pH}$ which caused an increase in pore size and change its nature of porosity. 
Table 5. Porosity measurement (BET) of Silica particles synthesized at different $\mathrm{pH}$ values.

\begin{tabular}{ccccc}
\hline Sample name & $\begin{array}{c}\text { Treatment } \\
\text { temperature (K) }\end{array}$ & $\begin{array}{c}\text { BET surface } \\
\text { area }\left(\mathrm{m}^{2} / \mathrm{g}\right)\end{array}$ & $\begin{array}{c}\text { Total pore } \\
\text { volume }\left(\mathrm{cm}^{3} / \mathrm{g}\right)\end{array}$ & Conclusion \\
\hline $\mathrm{S}_{1}(\mathrm{pH} 3)$ & 473 & 119 & 0.10 & Micro porous (43\%) \\
$\mathrm{S}_{2}$ (pH 5) & 473 & 35 & 0.09 & $\begin{array}{c}\text { Micro porous (32\%) } \\
\text { Mesoporous (50\%) }\end{array}$ \\
$\mathrm{S}_{3}(\mathrm{pH} 8)$ & 473 & 56 & 0.42 & Mesoporous (80\%) \\
$\mathrm{S}_{4}(\mathrm{pH} \mathrm{10)}$ & 473 & 67 & 0.68 & $\begin{array}{c}\text { Mesoporous (70\%) } \\
\text { Macro porous (30\%) }\end{array}$ \\
$\mathrm{S}_{5}(\mathrm{pH} \mathrm{12)}$ & 473 & 18 & 0.13 & Macro porous (70\%) \\
\hline
\end{tabular}

\section{Conclusion}

A potentially gratifying non-pathogenic bacterium arbitrates green synthesis of silica particles from organic silica precursor (TEOS) at different $\mathrm{pH}$ is successfully established presently. The as-prepared samples were thoroughly characterized by different techniques and tools including UV-Vis spectra, XRD, FE-SEM, EDX, BET, Zeta Potential, Raman spectra and FTIR spectra. The values of Zeta potential $(\zeta)$ of the silica particles implies the stability of synthesized synthesised silica particles in neutral $\mathrm{pH}$ atmosphere, preventing it from the auxiliary agglomeration. As a conclusion from BET measurement, it is revealed that the BET surface area decreases with increasing $\mathrm{pH}$ which causes an increase in pore size and change its nature of porosity. Peaks intensities are increasing on increasing of the specific surface as well as the value of $\mathrm{pH}$ as reveal from Raman spectra. In conclusion, silica leaching bacterial plausible proteins called bioremediaseis responsible for such process. The formation of silica particles via a simple biocompatible protein mediated way indicates that with this green methodology, uniform spherical and significant reduced particle size with plausible potential application as chromatographic packing having variable porosity can be obtained.

\section{Acknowledgements}

The work was performed by the authors own support. The experimental facilities obtained from Biophysical Laboratory of Physics Department of Jadavpur University are gratefully acknowledged.

\section{Conflict of Interests}

The authors declare that there is no conflict of interests regarding the publication of this paper.

\section{References}

[1] Jacobs, P.A., Flanigen, E.M., Jansen, J.C. and Bekkum, H.V. (2001) Introduction to Zeolite Science and Practice: Studies in Surface Science and Catalysis. 2nd Edition, Volume 137. Elsevier Science, New York.

[2] Lu, G.Q.M. and Zhao, X.S. (2004) Series on Chemical Engineering, Nanoporous Materials: Science and Engineering. 4th Edition, Imperial College Press, New York. 
[3] Ertl, G., Zinger, H.K. and Weitkamp, J. (1997) Handbook of Heterogeneous Catalysis. VCH, Weinheim, Germany. https://doi.org/10.1002/9783527619474

[4] Taguchi, A. and Schu, F. (2005) Ordered Mesoporous Materials in Catalysis. Microporous and Mesoporous Materials, 77, 1-45. https://doi.org/10.1016/j.micromeso.2004.06.030

[5] Corma, A. (1997) From Microporous to Mesoporous Molecular Sieve Materials and Their Use in Catalysis. Chemical Reviews, 97, 2373-2420. https://doi.org/10.1021/cr960406n

[6] Kruk, M., Jarnoniec, M., Joo, S.H. and Ryoo, R. (2003) Characterization of Regular and Plugged SBA-15 Silicas by Using Adsorption and Inverse Carbon Replication and Explanation of the Plug Formation Mechanism. The Journal of Physical Chemistry B, 107, 22052213. https://doi.org/10.1021/jp0271514

[7] Soler-Illia, G.J.A.A., Sanchez, C., Lebeau, B. and Patarin, J. (2002) Chemical Strategies to Design Textured Materials: From Microporous and Mesoporous Oxides to Nanonetworks and Hierarchical Structures. Chemical Reviews, 102, 4093-4138.

https://doi.org/10.1021/cr0200062

[8] Unger, K.K. (1990) Packings and Stationary Phases in Chromatographic Techniques. Marcel Dekker, New York.

[9] Kirkland, J.J., Henderson, J.W., DeStefano, J.J., Straten, M.A.V. and Claessens, H.A. (1997) Stability of Silica-Based, Endcapped Columns with pH 7 and 11 Mobile Phases for Reversed-Phase High-Performance Liquid Chromatography. Journal of Chromatography A, 762, 97-112. https://doi.org/10.1016/S0021-9673(96)00945-4

[10] Unger, K.K., Becker, N. and Roumeliotis, P. (1976) Recent Developments in the Evaluation of Chemically Bonded Silica Packings for Liquid Chromatography. Journal of Chromatography, 125, 115-127.

[11] Unger, K.K. (1979) Porous Silica. Journal of Chromatography Library, 16, 237-242.

[12] Kaide, A. and Saeki, T. (2014) Development of Preparation Method to Control Silica Sol-Gel Synthesis with Rheological and Morphological Measurements. Advanced Powder Technology, 25, 773-779. https://doi.org/10.1016/j.apt.2013.11.010

[13] Iler, R.K. (1993) The Chemistry of Silica. Wiley Interscience, Hoboken.

[14] Stober, W., Fink, A. and Bohn, E. (1968) Controlled Growth of Monodisperse Silica Spheres in the Micron Size Range. Journal of Colloid and Interface Science, 26, 62-69. https://doi.org/10.1016/0021-9797(68)90272-5

[15] Bogush, G.H. and Zukoski, C.F. IV. (1986) Proceedings of Microstructures. Berkeley, CA.

[16] Park, S.K., Kim, K.D. and Kim, H.T. (2002) Preparation of Silica Nanoparticles: Determination of the Optimal Synthesis Conditions for Small and Uniform Particles. Colloids and Surfaces A: Physicochemical and Engineering Aspects, 197, 7-17. https://doi.org/10.1016/S0927-7757(01)00683-5

[17] Biswas, M., Majumdar, S., Chowdhury, T., Chattopadhyay, B.D., Mandal, S., Halder, U. and Yamasaki, S. (2010) Bioremediase a Unique Protein from a Novel Bacterium BKH1, Ushering a New Hope in Concrete Technology. Enzyme and Microbial Technology, 46, 581587. https://doi.org/10.1016/j.enzmictec.2010.03.005

[18] Ghosh, P., Mandal, S., Chattopadhyay, B.D. and Pal, S. (2005) Use of Microorganism to Improve the Strength of Cement Mortar. Cement and Concrete Research, 35, 1980-1983. https://doi.org/10.1016/j.cemconres.2005.03.005

[19] Show, S., Tamang, A., Chowdhury, T., Mandal, D. and Chattopadhyay, B.D. (2015) Bacterial (BKH1) Assisted Silica Nanoparticles from Silica Rich Substrates: A Facile and Green Approach for Biotechnological Applications. Colloids and Surfaces B: Biointerfaces, 126, 
245-250. https://doi.org/10.1016/j.colsurfb.2014.12.039

[20] Kurumoto, N., Yamada, T. and Uchino, T. (2007) Enhanced Blue Photoluminescence from SiCl4-Treated Nanometer-Sized Silica Particles. Journal of Non-Crystalline Solids, 353, 684-686. https://doi.org/10.1016/j.jnoncrysol.2006.10.036

[21] Mohanty, T., Mishra, N.C., Bhat, S.V., Basu, P.K. and Kanjilal, D. (2003) Dense Electronic Excitation Induced Defects in Fused Silica. Journal of Physics D, 36, 3151-3155. https://doi.org/10.1088/0022-3727/36/24/010

[22] Neves, M.C., Trindade, T. and Peres, M. (2005) Photoluminescence of Zinc Oxide Supported on Submicron Silica Particles. Materials Science and Engineering C, 25, 654-657. https://doi.org/10.1016/j.msec.2005.06.019

[23] Skuja, L., Uttler, B.G., Schiel, D. and Silin, A.R. (1998) Infrared Photoluminescence of Pre-Existing or Irradiation-Induced Interstitial Oxygen Molecules in Glassy $\mathrm{SiO}_{2}$ and $\alpha$ Quartz. Physical Review B, 58, 14296-14304. https://doi.org/10.1103/PhysRevB.58.14296

[24] Jafarzadeh, M., Rahman, I.A. and Sipaut, C.S. (2010) Optical Properties of Amorphous Organo-Modified Silica Nanoparticles Produced via Co-Condensation Method. Ceramics International, 36, 333-338. https://doi.org/10.1016/j.ceramint.2009.09.010

[25] Alessi, A., Agnello, S., Buscarino, G. and Gelardi, F.M. (2013) Structural Properties of Core and Surface of Silica Nanoparticles Investigated by Raman Spectroscopy. Journal of Raman Spectroscopy, 44, 810-816. https://doi.org/10.1002/jrs.4292

\section{Submit or recommend next manuscript to SCIRP and we will provide best service for you:}

Accepting pre-submission inquiries through Email, Facebook, LinkedIn, Twitter, etc.

A wide selection of journals (inclusive of 9 subjects, more than 200 journals)

Providing 24-hour high-quality service

User-friendly online submission system

Fair and swift peer-review system

Efficient typesetting and proofreading procedure

Display of the result of downloads and visits, as well as the number of cited articles

Maximum dissemination of your research work

Submit your manuscript at: http://papersubmission.scirp.org/

Or contact aim@scirp.org 